\title{
Viruses associated with acute respiratory infections 1961-71
}

\author{
By P. G. HIGGINS \\ Virus Laboratory, Public Health Laboratory Service,* \\ 86 Dyer Street, Cirencester, Gloucestershire
}

(Received 2 October 1973)

\section{SUMMARY}

Influenza-like illness, cold and sore throat was the diagnosis given in over $80 \%$ of 5177 acute respiratory illnesses in patients swabbed over a 10-year-period. A pathogenic organism was isolated twice as frequently from patients with a sore throat or an influenza-like illness as from those diagnosed as suffering from croup or laryngitis and bronchitis. A laboratory diagnosis was commoner in school children than in older or younger persons.

Most of the organisms isolated were found in association with all types of acute respiratory illness but, with increasing age of the patient, one particular agent or group of agents was more likely to be of aetiological significance.

\section{INTRODUCTION}

Over a 10 year period specimens were collected by general practitioners from patients under their care and submitted to the virus laboratory at Cirencester for isolation studies. The majority of these specimens were from patients thought to have an acute respiratory infection and in this paper the results of the virological examination of these illnesses have been used in an attempt to determine the relation between the nature of the illness and the infecting agent.

\section{MATERIALS AND METHODS}

The population studied, the type of specimens collected and the methods used to examine them have been described previously (Higgins, 1974).

\section{RESULTS}

Between October 1961 and September 1971 nose and throat swabs were received from 5177 acute respiratory infections of which $1243(24.0 \%)$ were in pre-school children less than 5 years old, $1091(21.1 \%)$ in school children between the ages of 5 and 15 years, $2837(54 \cdot 8 \%)$ in patients 16 years of age or older and in $6(0 \cdot 1 \%)$ the age of the patient was not recorded. Further sub-division of these three age groups was not possible because the number of specimens and organisms recovered from any one type of illness would have become too small for analysis. For similar reasons the agents isolated have been considered in groups rather than individual serotypes.

* Present address: Virus Reference Laboratory, Central Public Health Laboratory, Colindale Avenue, London NW9 5HT. 
Table 1. Distribution of the patients sampled by age and clinical diagnosis

\begin{tabular}{|c|c|c|c|c|c|}
\hline \multirow[b]{2}{*}{$\begin{array}{c}\text { Clinical } \\
\text { illness }\end{array}$} & \multicolumn{5}{|c|}{ Age of patient } \\
\hline & $0-4$ years & 5-15 years & $\begin{array}{l}16 \text { years } \\
\text { and over }\end{array}$ & Not known & All ages \\
\hline Cold & $369(29 \cdot 7)$ & $229(21 \cdot 0)$ & $833(29 \cdot 4)$ & $1(16 \cdot 7)$ & $1432(27 \cdot 7)$ \\
\hline Sore throat & $126(10 \cdot 1)$ & $370(33.9)$ & $548(19 \cdot 3)$ & - & $1044(20 \cdot 2)$ \\
\hline Croup or laryngitis & $58(4 \cdot 7)$ & $20(1 \cdot 8)$ & $88(3 \cdot 1)$ & - & $166(3 \cdot 2)$ \\
\hline Tracheitis & $93(7 \cdot 5)$ & $70(6.4)$ & $145(5 \cdot 1)$ & - & $308(5.9)$ \\
\hline Bronchitis & $47(3 \cdot 8)$ & $21(1.9)$ & $112(3.9)$ & - & $180(3.5)$ \\
\hline Bronchiolitis & $150(12 \cdot 1)$ & $12(1 \cdot 1)$ & $11(0 \cdot 4)$ & - & $173(3 \cdot 3)$ \\
\hline Pneumonia & $7(0 \cdot 6)$ & $6(0 \cdot 6)$ & $34(1 \cdot 2)$ & - & $47(0.9)$ \\
\hline Influenza & $391(31 \cdot 4)$ & $356(32 \cdot 6)$ & $1053(37 \cdot 1)$ & $5(83 \cdot 3)$ & $1805(34 \cdot 9)$ \\
\hline Not known & $2(0 \cdot 2)$ & $7(0 \cdot 6)$ & $13(0.5)$ & - & $22(0 \cdot 4)$ \\
\hline All illnesses & 1243 & 1091 & 2837 & 6 & 5177 \\
\hline
\end{tabular}

Figures in parentheses $=$ percentage of total sample from age group.

Influenza-like illnesses, colds and sore throats accounted for $83 \%$ of the illnesses sampled whereas tracheitis, bronchitis, bronchiolitis and croup or laryngitis each represented between 3 and $6 \%$ of the total illnesses examined virologically. Pneumonia was the only type of illness of which less than 100 cases were examined.

The proportion of the total number of specimens taken from each of the three age groups from patients with any one of the eight clinical diagnoses is shown in Table 1. Cases of bronchiolitis formed a much greater portion of the total samples from pre-school children than from school children or adults. Patients with a sore throat constituted twice and three times as large a proportion of the samples from adults and school children respectively than that from pre-school children. The commonest clinical condition swabbed in children of school age was a sore throat and such cases formed a third of the sample obtained from patients in this age group, whereas cases of croup or laryngitis, bronchitis and common cold figured less prominently than in the other two age groups. In older persons influenzalike illnesses and pneumonia formed a slightly larger proportion of the total sample than in younger persons.

\section{Laboratory diagnosis}

The relation between the ability to make a laboratory diagnosis and the clinical diagnosis is summarized in Table 2. In this respect illnesses fell into one of four groups. A diagnosis by the isolation of a human pathogen was made in over $40 \%$ of cases of sore throat and influenza-like illness, over $35 \%$ of cases of tracheitis and bronchiolitis, over $30 \%$ of cases of pneumonia and common cold but in only $20 \%$ of cases of croup or laryngitis and bronchitis. A laboratory diagnosis was more common in school children $(43.3 \%)$ than in either pre-school children $(36.5 \%)$ or adults $(34 \cdot 1 \%)$. The greater success with material from school children was the result of the relatively high isolation rates in this age group, from cases of sore throat, tracheitis and influenza-like illness - illnesses which represent almost threequarters of the sample taken from children between the ages of 5 and 15 years.

An infecting agent was more frequently demonstrated in cases of croup or 
Table 2. Isolation rates by clinical diagnosis and age of patient

\begin{tabular}{|c|c|c|c|c|c|}
\hline \multirow[b]{2}{*}{$\begin{array}{l}\text { Clinical } \\
\text { illness }\end{array}$} & \multicolumn{5}{|c|}{ Age of patient } \\
\hline & $0-4$ years & 5-15 years & $\begin{array}{l}16 \text { years } \\
\text { and over }\end{array}$ & Not known & All ages \\
\hline Cold & $\begin{array}{l}113 / 369 \\
(30 \cdot 6)\end{array}$ & $\begin{array}{l}67 / 229 \\
(29 \cdot 3)\end{array}$ & $\begin{array}{l}252 / 833 \\
(30 \cdot 3)\end{array}$ & $0 / 1$ & $\begin{array}{l}432 / 1432 \\
(30 \cdot 2)\end{array}$ \\
\hline Sore throat & $\begin{array}{l}55 / 126 \\
(43 \cdot 7)\end{array}$ & $\begin{array}{l}200 / 370 \\
(54 \cdot 1)\end{array}$ & $\begin{array}{l}193 / 548 \\
(35 \cdot 2)\end{array}$ & - & $\begin{array}{l}448 / 1044 \\
(42 \cdot 9)\end{array}$ \\
\hline Croup or laryngitis & $\begin{array}{c}19 / 58 \\
(32 \cdot 8)\end{array}$ & $\begin{array}{c}2 / 20 \\
(10 \cdot 0)\end{array}$ & $\begin{array}{l}17 / 88 \\
(19 \cdot 3)\end{array}$ & - & $\begin{array}{l}38 / 166 \\
(22 \cdot 9)\end{array}$ \\
\hline Tracheitis & $\begin{array}{l}31 / 93 \\
(33 \cdot 3)\end{array}$ & $\begin{array}{c}30 / 70 \\
(42 \cdot 9)\end{array}$ & $\begin{array}{c}47 / 154 \\
(32 \cdot 4)\end{array}$ & - & $\begin{array}{l}108 / 308 \\
(35 \cdot 1)\end{array}$ \\
\hline Bronchitis & $\begin{array}{l}12 / 47 \\
(25 \cdot 5)\end{array}$ & $\begin{array}{c}4 / 21 \\
(19 \cdot 0)\end{array}$ & $\begin{array}{l}21 / 112 \\
(18 \cdot 8)\end{array}$ & - & $\begin{array}{l}37 / 180 \\
(20 \cdot 6)\end{array}$ \\
\hline Bronchiolitis & $\begin{array}{l}55 / 150 \\
(36 \cdot 7)\end{array}$ & $\begin{array}{c}3 / 12 \\
(25 \cdot 0)\end{array}$ & $\begin{array}{c}3 / 11 \\
(27 \cdot 3)\end{array}$ & - & $\begin{array}{l}61 / 173 \\
(35 \cdot 3)\end{array}$ \\
\hline Pneumonia & $\begin{array}{r}1 / 7 \\
(14 \cdot 3)\end{array}$ & $\begin{array}{r}2 / 6 \\
(33 \cdot 3)\end{array}$ & $\begin{array}{c}12 / 34 \\
(35 \cdot 3)\end{array}$ & - & $\begin{array}{l}15 / 47 \\
(31 \cdot 9)\end{array}$ \\
\hline Influenza & $\begin{array}{l}164 / 391 \\
(41 \cdot 9)\end{array}$ & $\begin{array}{l}164 / 356 \\
(46 \cdot 1)\end{array}$ & $\begin{array}{l}420 / 1053 \\
(39 \cdot 9)\end{array}$ & $0 / 5$ & $\begin{array}{l}748 / 1805 \\
(41 \cdot 4)\end{array}$ \\
\hline Not known & $\begin{array}{r}1 / 2 \\
(50 \cdot 0)\end{array}$ & $\begin{array}{r}1 / 7 \\
(14 \cdot 3)\end{array}$ & $\begin{array}{c}2 / 13 \\
(15 \cdot 4)\end{array}$ & - & $\begin{array}{c}4 / 22 \\
(18 \cdot 2)\end{array}$ \\
\hline All illnesses & $\begin{array}{l}451 / 1243 \\
(36 \cdot 5)\end{array}$ & $\begin{array}{l}473 / 1091 \\
(43 \cdot 4)\end{array}$ & $\begin{array}{l}967 / 2837 \\
(34 \cdot 1)\end{array}$ & $0 / 6$ & $\begin{array}{c}1891 / 5177 \\
(36 \cdot 5)\end{array}$ \\
\hline
\end{tabular}

Numerator $=$ number of isolations. Denominator $=$ number of specimens examined. Figures in parentheses $=$ percentage of specimens yielding a pathogen .

laryngitis in the 0 to 4 year old group than older persons as was seen also with bronchiolitis. However, the significance of the latter finding, like the low isolation rate in pneumonia in pre-school children, remains doubtful because of the small number of specimens received from these illnesses in at least two of the age groups.

\section{Viruses associated with different clinical diagnoses}

The relation between the clinical diagnosis and the infecting organism is shown in Fig. 1.

Colds. Rhinoviruses were the commonest agent found in association with the common cold and they were isolated from over $10 \%$ of specimens from children and $20 \%$ of specimens from adults with this clinical illness. In school children myxoviruses, and in all children under 16 years of age the paramyxoviruses, were isolated from approximately $5 \%$ of the specimens received.

Sore throats. Streptococci were the most frequently encountered organism in cases of sore throat except in pre-school children where they were second in importance to the enteroviruses. Enteroviruses, adenoviruses and herpes simplex virus were all found in association with this clinical condition but with reduced frequency as the age of the patient increased. In addition, paramyxoviruses in pre-school children, myxoviruses in school children and rhinoviruses in adults, made a significant contribution to the aetiology of sore throats. 

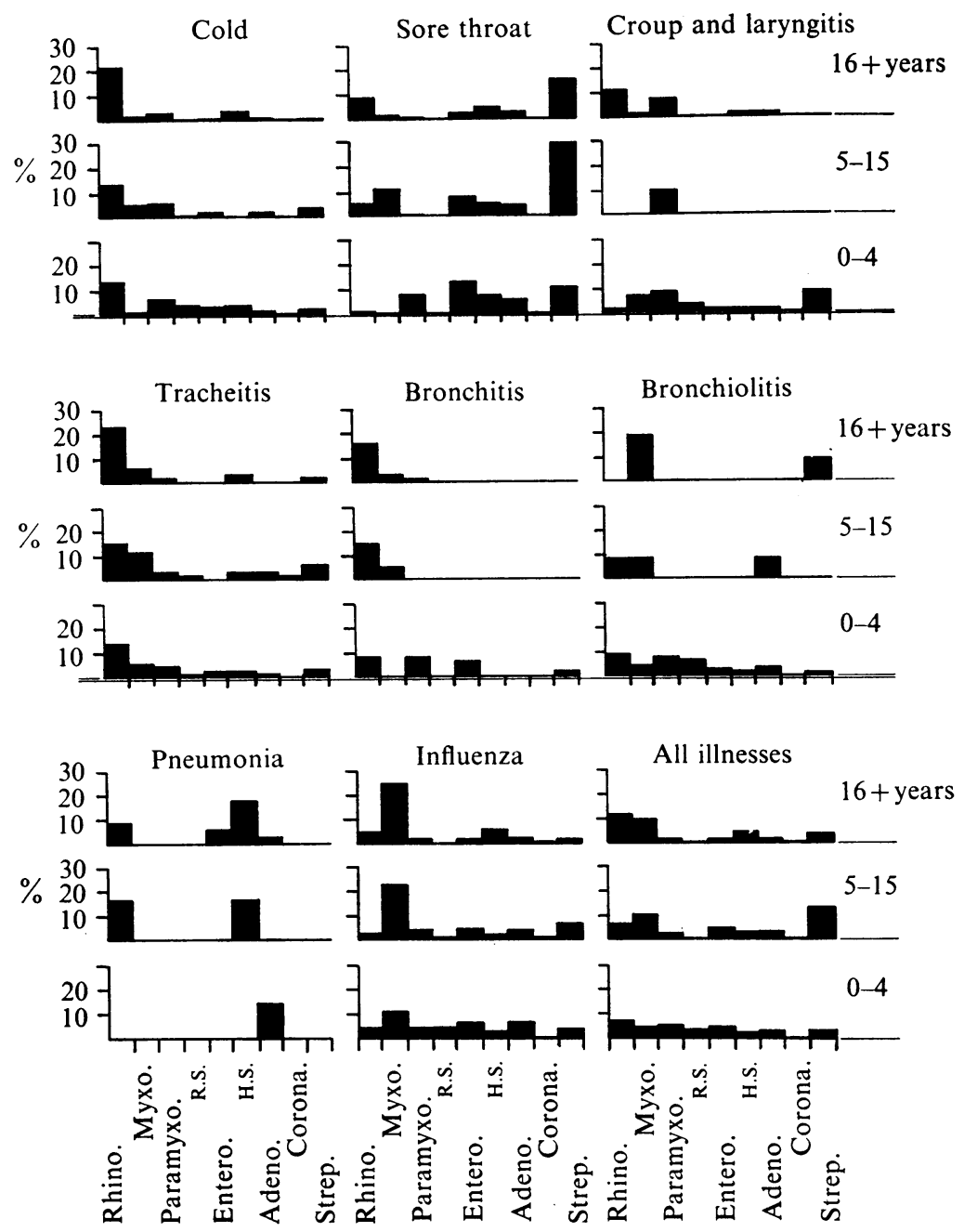

Fig. 1. Relation between clinical illness, age of patient and infecting agent. Rhino, Rhinoviruses; Myxo, Myxoviruses; Paramyxo, Paramyxoviruses; R.s., Respiratory syncytial virus H.S., Herpes simplex virus; Adeno, Adenoviruses; Corona, Coronaviruses; Strep, Streptococci groups A, C or G.

Croup or laryngitis. In school children paramyxoviruses were the only diagnosed cause of these conditions and with the rhinoviruses accounted for most of the proved infections in adults. Pre-school children with croup yielded a wider range of organisms with myxoviruses, paramyxoviruses and streptococci as the three most important.

Tracheitis. In all age groups rhinoviruses were the commonest agents isolated from cases of tracheitis and with a slightly higher frequency than from patients suffering from a cold. Myxoviruses were also of importance in all age groups but especially school children, and other agents were found in association with a small number of cases, notably in children.

Bronchitis. As with colds and tracheitis, rhinoviruses were the commonest 
organism associated with bronchitis. Myxoviruses in school children and paramyxoviruses and enteroviruses in pre-school children were responsible for a smaller number of illnesses.

Bronchiolitis. Only three isolations were made from patients in each of the two older age groups and any conclusions drawn from these findings may be misleading. Of the 55 isolations from pre-school children with illnesses given this diagnosis, rhinoviruses, paramyxoviruses and respiratory syncytial virus were the commonest agents isolated but other viruses were also associated with this clinical illness in a smaller proportion of cases.

Pneumonia. Only in adults were sufficient agents isolated from patients with pneumonia to allow comment to be made. The commonest virus encountered was herpes simplex virus and, of the other agents, only rhinoviruses and enteroviruses were isolated from more than $5 \%$ of cases examined.

Influenza-like illnesses. By far the commonest agent isolated, at all ages, from cases of influenza was a myxovirus. In adults herpes simplex virus and in school children streptococci were the only other agents isolated from more than $5 \%$ of the specimens. In young children less than 5 years old, most viruses played a significant role in the causation of influenza-like illnesses although myxoviruses were the most important.

All respiratory illnesses. Respiratory illnesses in pre-school children most commonly yielded a rhinovirus, and coronaviruses were seldom found. All the remaining agents were isolated from between 3 and $6 \%$ of specimens. Streptococci of groups A, C, or G and myxoviruses were each found in more than $10 \%$ of specimens from school children whereas only rhinoviruses of the other agents were encountered in more than $5 \%$ of specimens. Rhinoviruses and myxoviruses were each isolated from more than $10 \%$ of specimens from adults but herpes simplex, the next commonest agent, was recovered from less than $5 \%$ of patients.

\section{Clinical diagnosis in cases of proved infection with different agents}

Of the 5177 specimens from acute respiratory infections $1891(36.5 \%)$ yielded a virus or streptococcus belonging to groups A, C or G. The proportion of the total number of strains of any one group of viruses or streptococci associated with each of the eight clinical diagnoses is shown in Fig. 2. With the possible exception of respiratory syncytial virus, of which only seven strains were isolated from patients over the age of 5 years, the differences in these proportions between the three age groups were small and the results have been analysed for patients of all ages combined.

Approximately half (252) of the 496 rhinoviruses isolated were recovered from patients with a cold and a further $30 \%$ were found in specimens from patients with a sore throat, tracheitis or an influenza-like illness. Over $80 \%$ of the 462 myxoviruses isolated were from patients with influenza and no other form of illness yielded more than $5 \%$ of the total number of strains isolated. Infection with one of the 148 paramyxoviruses isolated most commonly resulted in a cold (38\% of strains) and of the other diagnoses only influenza-like illnesses (29\% of strains) accounted for more than $10 \%$ of the total number of viruses of this group that were 


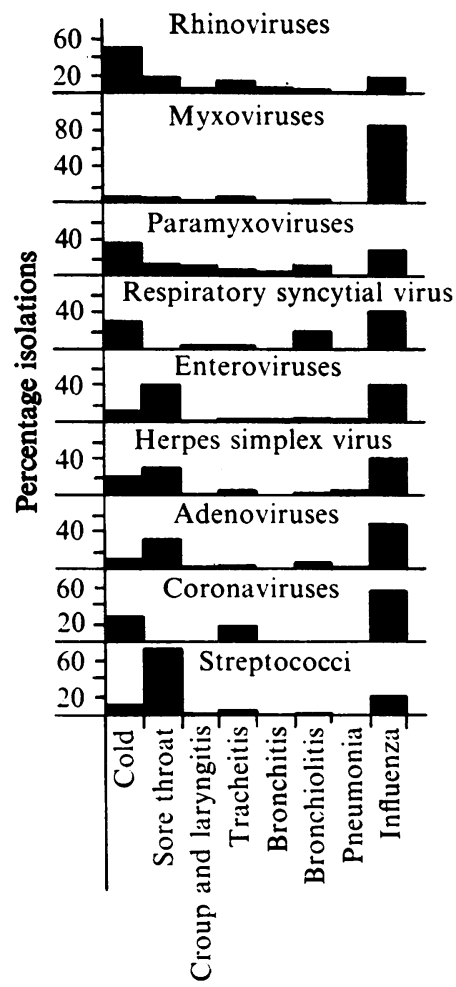

Fig. 2. Distribution of proved infections by diagnosis.

detected. Forty-nine strains of respiratory syncytial virus were isolated, most frequently $(41 \%)$ from cases of influenza-like illnesses but the common cold $(31 \%)$ and bronchiolitis $(20 \%)$ were also common sources of this virus.

Enterovirus isolations totalled 138, mainly from cases of influenza-like illness and sore throat, $40 \%$ each, and $11 \%$ of strains were isolated from cases of the common cold.

Herpes simplex virus, 181 strains, was most commonly associated with influenzalike illnesses $(40 \%)$ but $29 \%$ of strains were isolated from cases of sore throat and $20 \%$ from those with colds.

Adenoviruses were isolated on 119 occasions. Most strains were from patients with influenza-like illness $(48 \%$ ) but $31 \%$ were found in patients with a sore throat and $10 \%$ in those with a cold.

Coronaviruses were isolated on $\mathbf{7}$ occasions only, from patients with an influenzalike illness, tracheitis or a common cold.

Streptococci of groups A, C or G-291 strains were found, over $70 \%$ of which were associated with a sore throat. Influenza-like illnesses yielded more than half of the remaining strains detected. 


\section{DISCUSSION}

The lack of standardization of the clinical diagnoses among the various practitioners submitting specimens, and the absence of a random sampling system were two shortcomings of this study. Thus two identical illnesses could receive different diagnoses, and a biased selection of cases could invalidate the apparent frequency with which certain clinical illnesses resulted from infection with a particular group of viruses. Furthermore, differences in the ease with which different infecting agents can be isolated will affect the apparent importance of each group of agents.

If these limitations are accepted it will be realized that the observations made in this study are only an indication of the relation between the various organisms isolated and the clinical illness diagnosed. However, because the subjects studied were members of the general community the results are more likely to be related to the natural history of the infecting agents than those from investigations which are biased by the use of a selected population such as children in hospital or students.

This study has shown that most of the agents isolated are associated with all types of acute respiratory illnesses. However, their relative importance as causal agents of illnesses given a specific diagnosis varies with the age of the patient. The aetiology of all acute respiratory infections in young children under 5 years of age is broadly based in terms of infecting agents but in adults there is commonly one predominant organism which accounts for between 50 and $70 \%$ of the agents associated with a particular clinical diagnosis.

The range of clinical illness found to be associated with proved infections has confirmed that all the agents isolated could be found in patients whose illness had been given any one of the clinical diagnoses used. However some types of illness were observed much more frequently as the result of infection with one agent than with another, e.g. rhinovirus infections commonly gave rise to colds, and myxovirus infections to influenza-like illnesses.

Coronaviruses were sought and isolated less often than any other group of viruses but the clinical illness with which they were associated was not restricted to an upper respiratory infection as has commonly been found previously (Hamre \& Procknow, 1966; Bradburne, Bynoe \& Tyrrell, 1967; McIntosh et al. 1967; Kapikian et al. 1969).

Although the specimens in this study were examined more extensively than in many earlier surveys, a diagnosis by isolation was made in only $36.5 \%$ of cases studied. Until the examination of material from acute respiratory infections is more profitable it will not be possible to be certain how accurately this type of study reflects the true relation between clinical illness and virus infection. 


\section{REFERENCES}

Bradburne, A. F., Bynoe, M. L. \& Tyrrell, D. A. J. (1967). Effects of a 'new' human respiratory virus in volunteers. British Medical Journal iii, 767-9.

Hamre, D. \& Procknow, J. J. (1966). A new virus isolated from the human respiratory tract. Proceedings of the Society for Experimental Biology and Medicine 121, 190-3.

Higarns, P. G. (1974). Virus isolations from patients in general practice 1961-71. Journal of Hygiene 72, 255.

Kapikian, A. Z., James, H. D., Kelly, Sarah J., Dees, Jane H., Turner, H.C., McIntosh, K., Kim, H. W., Parrott, R. H., Vincent, M. M. \& Chanock, R. M. (1969). Isolation from man of 'Avian infectious bronchitis virus-like' viruses (coronaviruses) similar to $229 \mathrm{E}$ virus, with some epidemiological observations. Journal of Infectious Diseases 119, 282-90.

McIntosh, K., Dees, Jane H., Becker, W. B., Kapikian, A. Z. \& Chanock, R. M. (1967). Recovery in tracheal organ cultures of novel viruses from patients with respiratory diseases. Proceedings of the National Academy of Sciences of the U.S.A. 57, 933-40. 